\title{
Missbrauch des Flüchtlingsrechts?
}

\author{
Subjektive Nachfluchtgründe am Beispiel der religiösen Konversion
}

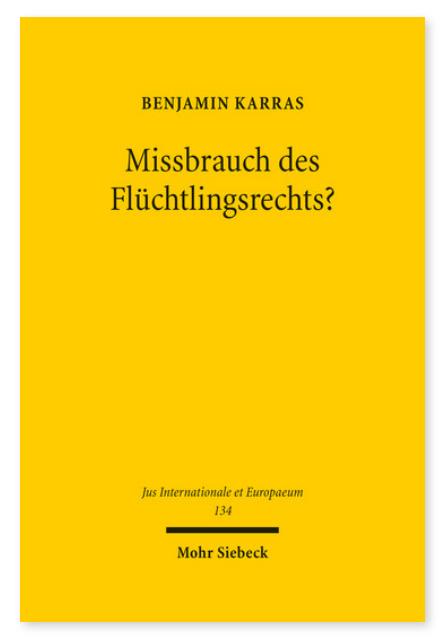

2017. XVII, 326 Seiten. JusIntEu 134

ISBN 978-3-16-155617-3

DOI 10.1628/978-3-16-155617-3

eBook PDF 104,00€

ISBN 978-3-16-155616-6

Leinen $104,00 €$
Das Flüchtlingsrecht ist als Verfolgungsschutzrecht dazu konzipiert, künftig drohenden Menschenrechtsverletzungen vorzubeugen. Gleichwohl dominiert in Praxis und Literatur bisweilen der Blick in die Vergangenheit. Besonders prominent ist dies in Fällen sogenannter Nachfluchtgründe zu beobachten, also in Konstellationen, in denen erst im Aufnahmeland Umstände begründet werden, die eine Verfolgungsgefahr entstehen lassen. Gerade wenn die drohende Verfolgung auf Handlungen des Migranten zurückzuführen ist, bleibt der Vorwurf des »Missbrauchs« nicht fern. Ausgehend vom Völker- und Europarecht legt Benjamin Karras dar, dass flüchtlingsrechtlich relevant einzig die zu erwartende Reaktion des Verfolgers und nicht die Aktion des (potentiell) Verfolgten ist. Anhand des historisch und aktuell bedeutsamen Anwendungsfalles der religiösen Konversion wird demonstriert, wie diese Vorgaben verwaltungsprozessual zur Geltung kommen können.

Benjamin Karras Geboren 1991; Studium der Rechtswissenschaften und fachspezifischer Fremdsprachenausbildung in Münster; Wissenschaftlicher Mitarbeiter am Institut für Öffentliches Recht und Politik in Münster; seit 2016 Rechtsreferendar am Landgericht Münster.

Jetzt bestellen:

https://mohrsiebeck.com/buch/missbrauch-des-fluechtlingsrechts-9783161556173?no_cache=1 order@mohrsiebeck.com

Telefon: +49 (0)7071-923-17

Telefax: $+49(0) 7071-51104$ 